\title{
Representasi Perempuan Muslim dalam Hati Suhita Karya Khilmi Anis
}

\author{
Indra Tjahyadi ${ }^{1}$ | Dheny Jatmiko
}

${ }^{1}$ Program Studi Sastra Inggris Universitas Panca Marga, Probolinggo

${ }^{2}$ Lembaga Pengabdian Masyarakat Univesitas 17 Agustus 1945, Surabaya

Correspondence: Indra Tjayadi

Program Studi Sastra Inggris Universitas Panca Marga, Probolinggo

indratjahyadi@upm.ac.id

\section{Article History:}

Received 3 November 2021 Revised 29 November 2021 Accepted 30 November 2021

\section{Abstract}

This article focuses on the existence of the meaning of Muslim women as represented in the novel Hati Suhita by Khilma Anis. In this study, the novel is not only understood as a literary work that has aesthetic value, but is also understood as a cultural document that represents the cultural discourse of a society. The purpose of this study is to describe the meaning of Muslim women represented in a novel type discourse entitled Hati Suhita by Khilma Anis. The theory used in this study is the theory of discourse analysis modeled by Ernesto Laclau and Chantal Mouffe. The method used in this study is descriptive qualitative method. Based on the analysis, it was found that in the novel Hati Suhita, Muslim women are represented as intelligent, strong personalities, and have the courage to actualize themselves in society.

Keywords: Hati Suhita, Khilma anis, moslem women, representation

\section{Abstrak}

Artikel ini memfokuskan kajiannya pada keberadaan makna perempuan muslim yang direpresentasikan dalam Hati Suhita karya Khilma Anis. Dalam kajian ini, novel tidak hanya dipahami sebagai sebuah karya sastra yang mimiliki nilai estetika saja, lebih jauh novel sebagai dokumen budaya yang merepresentasikan wacana kebudayaan sebuah masyarakat. Tujuan penelitian ini untuk mendeskripsikan makna perempuan muslim yang direpresentasi dalam wacana berjenis novel. Teori yang digunakan dalam kajian ini teori analisis wacana model Ernesto Laclau dan Chantal Mouffe. Metode yang digunakan dalam kajian ini adalah metode kualitatif desktiptif. Berdasarkan analisis yang dilakukan ditemukan bahwa perempuan muslim direpresentasikan sebagai sosok yang cerdas, berkepribadian yang kuat, serta memiliki keberanian untuk mengaktualisasikan dirinya di tengah masyarakat.

Kata Kunci: Hati Suhita, Khilma Anis, perempuan muslim, representasi, 


\section{Pendahuluan}

Perempuan muslim masih menjadi topik yang menarik untuk dikaji saat ini. Hal tersebut disebabkan posisi perempuan dalam masyarakat muslin di Indonesia yang masih problematik. Sebagaimana masyarakat muslim pada umumnya, muslim di Indonesia juga didominasi sistem patriarki sebagai landasan sistem sosial budaya. Menurut ElSaadawi (2011) sistem patriarki merupakan sistem budaya yang menempatkan perempuan dalam posisi yang sulit. Dalam sistem tersebut, perempuan diposisikan hanya sebagai objek, dan bukan subjek. Dalam arti eksistensi perempuan dalam sistem sosial ditentukan oleh laki-laki. Oleh karena itu, dalam sistem tersebut, perempuan dimaknai sebagai warga masyarakat "kelas dua" di bawah laki-laki (Hanani, 2021).

Keberadaan perempuan sebagai objek dalam sistem patriarki, juga dapat dipahami dari pemosisian perempuan sebagai liyan yang otomatis menempatkan mereka berada di bawah dominasi laki-laki. Pemaknaan tersebut tampak pada keberadaan perempuan yang selalu ditempat pada dataran periferal, sebuah posisi subordinat yang memungkin untuk dikenai praktik dominasi. Oleh karena itu, sistem patriarki juga dipahami sebagai sistem budaya yang menempatkan perempuan sebagai subjek dominasi di bawah laki-laki (ElSaadawi, 2011).

Diskriminasi dan praktik dominasi terhadap perempuan oleh laki-laki masih jamak terjadi dalam masyarakat muslim di Indonesia. Keberadaan partriarki yang menjadi sistem sosial-budaya masyarakat muslim di Indonesia merupakan penyebab masih terjadinya praktik tersebut. Selain itu, kepercayaan yang memosisikan laki-laki sebagai pemimpin perempuan yang masih dipegang teguh oleh masyarakat tersebut turut menjadi faktor yang memungkinkan praktik diskriminasi dan dominasi terhadap perempuan. Hal tersebut sebenarnya merupakan hal yang tidak tepat. Dalam Islam laki-laki dimaknai sebagai "imam" bagi perempuan. Namun demikian, tidak berarti laki-laki lantas mensubordinasi perempuan. Dalam Islam, laki-laki dan perempuan memiliki derajat yang sama. Oleh karena itu, terdapat salah pembacaan dan pemaknaan terhadap posisi dan kedudukan perempuan dalam masyarakat muslim di Indonesia (Fabriar, 2013).

Artikel ini memfokuskan kajiannya pada pemaknaan perempuan muslim yang direpresentasikan dalam Hati Suhita (2019), sebuah novel yang ditulis oleh Khilma Anis. Dalam artikel ini, novel tersebut diposisikan sebagai objek material kajian. Adapun faktor pertama yang mendorong dipilihnya novel tersebut sebagai objek material dalam kajian ini adalah faktor intrinsik novel tersebut.

Hati Suhita karya Khilma Anis merupakan sebuah teks yang memiliki gaya penceritaan yang enak untuk dibaca. Pemilihan plot yang sederhana, dan penokohan serta pemilihan latar tempat dan waktu yang jelas menjadikan novel tersebut mudah dipahami. Hal tersebut didukung dengan tema menarik yang ditawarkan oleh novel tersebut. Sebagai perempuan yang dibesarkan dalam lingkungan pesantren, tema tentang pergulatan perempuan dalam masyarakat pesantren merupakan tema yang subversif bagi Khilma Anis (Haryanti \& Fakhriyah, 2020). Oleh karena itu, pemilihan tema novel yang subversif tersebut menjadi faktor kedua yang membuat Hati Suhita menarik untuk dikaji secara mendalam.

Faktor ketiga yang melatari dipilihnya Hati Suhita karya Khilma Anis sebagai objek material dalam kajian ini adalah popularitas novel tersebut. Menurut Anis (wawancara, 21 September 2019) Hati Suhita telah terjual sebanyak enam ribu eksemplar. Hal tersebut memperlihatkan bahwa novel tersebut memiliki popularitas yang tinggi bagi pembaca 
novel di Indonesia.

Dalam melakukan kajian, artikel ini mendasarkan analisisnya pada teori analisis wacana model Laclau dan Mouffe. Secara umum teori wacana tersebut merupakan teori analisis wacana yang berperspektif pascastrukturalisme dan konstruktivisme. Adapun perspektif pascastrukturalisme teori wacana Laclau dan Mouffe tampak pada pemahaman teori tersebut tentang makna.

Menurut Laclau dan Mouffe makna tidak pernah stabil. Makna selalu bersifat relatif. Hal tersebut disebabkan oleh upaya pembentukan makna yang selalu berada praktik penetapan relasirelasi antarelemen dalam satu momen artikulasi. Perubahan relasi antarelemen akan berdampak pada perubahan makna. Penetapan makna melalui wacana memang dapat dilakukan, tetapi hal tersebut hanya berlaku temporer. Oleh karena itu, tidak ada makna yang stabil. Makna selalu berada pada momen relatif. Pemahaman relativitas makna yang terdapat dalam teori wacana Laclau dan Mouffe itu sama dengan pemahaman makna teoriteori pascastrukturalisme (Jorgensen \& Phillips, 2007). Oleh karena itu, teori wacana Laclau dan Mouffe dapat dikategorikan sebagai teori wacana pascastrukturalisme.

Perspektif konstruktivisme teori wacana Laclau dan Mouffe tampak pada pemahaman teori tersebut mengenai realitas sosial. Menurut Laclau dan Mouffe (2008) realitas sosial merupakan produk dari praktik pengonstruksian wacana. Realitas sosial bukan sesuatu yang terberi. Realitas sosial merupakan produk dari praktik artikulasi wacana yang menetapkan makna atas objek-objek fisis di luar wacana. Maka, tanpa wacana, objek-objek fisis tidak akan menjadi realitas.

Berdasarkanpenjelasandiatasdapatlahdipahami bahwa wacana mengonstruksi makna objek, yang memungkinkan realitas diciptakan. Maka, realitas sosial bukanlah terberi, melainkan hasil kontruksi kewacanaan. Oleh karena itu, wacanalah, melalui praktik artikulasi, yang membangun realitas. Pada tataran itulah perspektif konstruktivisme teori wacana Laclau dan Mouffe berada. Hal tersebut sebagaimana yang pernah dinyatakan oleh Denzin dan Lincoln (2009) konstruktivisme adalah pendekatan yang memahami realitas sebagai produk pengonstruksian.

Dalam teori wacana Laclau dan Mouffe terdapat konsep-konsep penting yang menjadi unsur-unsur pembentuk teori tersebut. Konsep pertama adalah artikulasi, dipahami sebagai sebuah praktik pengomposisian ulang atas elemen-elemen. Pengompisisian tersebut dilakukan dengan cara merelasikan berbagai elemen ke dalam momenmomen. Tujuan dari praktik tersebut adalah memodifikasi elemen-elemen menjadi momen sehingga memungkinkan sebuah wacana terbangun (Laclau \& Mouffe, 2008).

Wacana merupakan konsep kedua yang terdapat dalam teori wacana Laclau dan Mouffe. Wacana merupakan produk dari praktik artikulasi. Menurut Laclau dan Mouffe (2008) wacana dapat didefinisikan sebagai totalitas terstruktur yang diproduksi melalui praktik artikulasi oleh artikulatoris. Dikatakan totalitas karena, dalam wacana, terdapat relasi elemen-elemen yang telah mengalami penghentian dalam momenmomen sehingga memungkinkan wacana untuk memproduksi makna. Makna, merupakan totalitas yang diproduksi oleh wacana. Adapun yang dimaksud dengan terstruktur, Laclau dan Mouffe memahami bahwa wacana memiliki elemen-elemen dan momen-momen sebagai unsur-unsur yang membangunnya.

Namun, upaya untuk memodifikasi elemenelemen ke dalam momen-momen melalui praktik perlasian elemen selalu mengalami gangguan. Kontingensi dan Antagonisme merupakan unsurunsur yang dapat memodifikasi relasi elemen- 
elemen sehingga tercipta kondisi ketidakstabilan makna. Menurut Laclau dan Mouffe (2008) kontingensi dapat merekomposisi momenmomen sehingga makna wacana terus mengalami ketidakstabilan. Kontingensi adalah faktor eksternal yang memungkinkan makna mengalami relativitasnya.

Adapun antagonisme dipahami Laclau dan Mouffe (2008) sebagai sistem pembeda antarelemen. Tanpa antogonisme, pembangunan relasi antarelemen tidak dapat dilakukan. Hal tersebut disebabkan karena praktik perelasian elemen-elemen dalam artikulasi hanya bisa dilakukan apabila elemenelemen tersebut memiliki nilai pembeda. Maka, tanpa antagonisme, artikulasi tidak dapat dilakukan.

Sedangkan metode yang digunakan dalam kajian ini adalah kualitatif deskriptif. Data primer dalam kajian adalah adalah berbagai kata, kalimat, dan alinea yang bermakna. Adapun data sekunder kajian ini adalah data-data tentang makna perempuan muslim di Indonesia. Analisis atas objek material dilakukan melalui beberapa tahapan dalam kajian. Tahapan pertama melakukan analisis deskripsi atas teks. Tahap kedua melakukan interpretasi atas deskripsi teks. Tahap ketiga melakukan eksplanasi atas interpretasi teks.

\section{Hasil dan Pembahasan}

Dalam teori Laclau dan Mouffe upaya untuk mengungkap makna wacana dapat dilakukan melalui momen-momen yang membentuk totalitas terstruktur wacana. Hal tersebut disebabkan keberadaan momen-momen yang berfungsi penghentian sementara atas relasi elemen-lemen. Dalam momen-momen fiksasi semantis yang bersifat relatif dilakukan. Maka analisis atas wacana perempuan dalam Hati Suhita karya Khilma Anis dilakukan dengan cara menganalisis makna perempuan yang terdapat dalam momen-momen dalam novel tersebut.
Dalam Hati Suhita, Khilma Anis menghadirkan momen perempuan sebagai mahluk yang kuat. Hal tersebut sebagaimana tampak pada kutipan berikut: Kadang aku ingin mengadu kepada orangtuaku, tapi kakek mengajarkanku untuk mikul duwur mendem jero .... Sebab aku adalah wanita. Kakek mengajarkan kepadaku bahwa wanita, adalah wani tapa, berani bertapa.

Inilah yang tak boleh kulupa; Tapa-TapakTelapak. Kakek mengajarkan itu karena di sanalah kekuatan seorang wanita berada. Tapa akan menghasilkan keteguhan diri. Tapa akan mewujud dalam tapak. Tapak adalah telapak. Kekuatan wanita ada di telapaknya, atau kasih sayangnya. Sesungguhnya di bawah telapak wanita eksistensi dan esensi surga berada (Anis, 2019).

Dalam momen di atas tampak keberadaan perempuan direlasikan dengan elemen-elemen yang bermakna kepasrahan, keikhlasan, kerendahhatian dan kemuliaan. Kalimat "kakek mengajarkanku untuk mikul duwur mendem jero ...." yang merupakan elemen dari kerendahhatian direlasikan dengan kalimat "aku adalah wanita. Kakek mengajarkan kepadaku bahwa wanita, adalah wani tapa, berani bertapa." yang merupakan elemen dari kepasrahan, keberanian, dan keikhlasan. Pengartikulasian tersebut mengonstruksi makna wacana perempuan sebagai mahluk yang kuat karena berani untuk melakukan kerendahhatian, kepasrahan, keikhlasan, meskipun dia tahu bahwa dirinya mahluk mulia.

Dalam momen tersebut stereotipe perempuan sebagai mahluk yang lemah, penakut, dan tidak berani menentukan sikap diekslusi oleh pengarang. Stereotipe tersebut posisikan oleh pengarang sebagai elemen-elemen yang tidak teratikulasikan dalam momen-momen. Pemaknaan stereotipe perempuan sebagai mahluk yang lemah, penakut, dan tidak berani menentukan sikap diletakkan dalam medan kewacanaan, yakni medan tempat 
elemen-elemen yang tidak teratikulasikan dalam momen-momen berada.

Selain mengonstruksikan perempuan sebagai mahluk yang kuat, tegar, dan tabah, sekaligus mulia, pengarang dalam novelnya juga mengonstruksikan wacana perempuan sebagai mahluk yang cerdas. Itu tampak pada perwatakan yang dimiliki oleh dua tokoh perempuan yang mendominasi cerita, yakni Alina Suhita dan Rara Rengganis. Dalam Hati Suhita, tokoh Alina Suhita tidak saja diartikulasikan oleh Anis, sebagai artikulatoris, sebagai sosok yang berwatak tegar, tetapi juga cerdas. Kecerdasan tokoh Alina tampak pada kemampuan tokoh tersebut untuk menganalogikan setiap peristiwa yang dialaminya dengan pengetahuan yang dimilikinya. Itu sebagaimana tampak pada kutipan berikut:

Mas Birru tidak tahu, ketika dia melemahkan orang lain, artinya dia membiarkan orang lain menyadari kekuatannya. Dia tak tahu, kepala Resi Drona yang terpenggal di padang Kurusetra, adalah perbuatan Drestajumna yang di dalam tubuhnya menitis dendam Ekalaya (Anis, 2019).

Dalam bidang ilmu bahasa, analogi dipahami sebagai persamaan dan persesuaian antara dua benda atau hal yang berlainan. Analogi merupakan jenis bahasa kiasan. Pembentukan analogi membutuhkan pengetahuan yang luas. Hal Tidak semua orang mampu untuk melakukan analogi antara realitas empiris dengan kecerdasan teoretis yang dimiliki. Hanya orang-orang yang memiliki kecerdasan dan kepintaran yang cukup baik yang memiliki kemampuan untuk mensintesiskan dan menghasilkan analogi antara pengetahuan dan realitas yang terjadi di hadapannya. Kemampuan untuk beranalogi dengan berbagai bacaan yang dimiliki oleh tokoh Alina Suhita merupakan upaya untuk mengonstruksi identitas tersebut sebagai tokoh yang berwatak cerdas.

Pengonstruksian identitas Alina Suhita sebagai tokoh yang berwatak cerdas dilakukan oleh Suhita melalui pengartikulasian tokoh Mas Birru sebagai antagonisme. Alina Suhita berantagonisme dengan Mas Birru. Antagonisme tersebut dilakukan agar identitas tokoh Alina Suhita dapat direlasikan dengan elemen manusia cerdas. Penempatan elemen Mas Birru yang direlasikan dengan sifat ketidaktahuan merupakan upaya Anis untuk membentuk momen pemaknaan atas tokoh Mas Biruu. Itu tampak pada pengartikulasian kalimat "Mas Birru tidak tahu, ketika dia melemahkan orang lain, artinya dia membiarkan orang lain menyadari kekuatannya." oleh Anis dalam novelnya tersebut.

Selain mengonstruksikan tokoh Alina Suhita sebagai tokoh yang berwatak cerdas, Anis juga membangun momen yang mengonstruksikan tokoh Alina Suhita sebagai tokoh yang cakap dan berani. Itu tampak pada kutipan berikut:

Kehebatan prajurit perempuan itu bahkan sampai membuat pejabat VOC keheranan melihat keterampilan Prajurit Estri sebagai prajurit berkuda. Ia yang terlatih secara militer, bisa takjub melihat prajurit perempuan Jawa menembakkan salvo dengan teratur dan tepat (Anis, 2019).

Kutipan di atas merupakan momen yang mengonstruksikan perempuan muslim sebagai mahluk yang berwatak cakap dan berani. Pengartikulasian kalimat Kehebatan prajurit perempuan itu bahkan sampai membuat pejabat VOC keheranan melihat keterampilan" oleh Anis dalam Hati Suhita merupakan upaya pengarang untuk menetapkan momen yang mengidentifikasi perempuan muslim sebagai mahluk yang berani, kuat, dan memiliki kecakapan. Pengartikulasian tersebut berdampak pada pengeksklusian elemenelemen yang mengidentifikasi perempuan sebagai subjek yang lemah, penakut, tidak memiliki kemampuan dari wacana perempuan muslim yang dikonstruksi oleh Anis dalam novelnya tersebut. Elemen-elemen perempuan muslim sebagai subjek yang lemah, penakut, tidak memiliki kecapakan 
diposisikan dalam medan kewacanaan. Itu berarti ada perubahan posisi subjek perempuan muslim dalam Hati Suhita karya Khilma Anis.

Sebagaimana yang dinyatakan oleh Laclau dan Mouffe (2008) wacana merupakan sebuah upaya untuk memodifikasi posisi-posisi subjek. Melalui praktik artikulasi, artikulatoris menata relasi elemen-elemen sehingga tercipta momenmomen yang memungkinkan posisi-posisi subjek mengalami perubahan. Dalam Hati Suhita, perubahan posisi-posisi perempuan muslim sebagai subjek yang lemah, penakut, tidak berkepribadian, bodoh, tidak memiliki kecakapan, dan tidak mandiri dieksklusi, sehingga posisi perempuan sebagai subjek mengalami perubahan.

Perubahan posisi subjek perempuan muslim yang terkonstruksi secara stereotipe sebagai subjek yang lemah, penakut, tidak berkepribadian, bodoh, tidak memiliki kecakapan, dan tidak mandiri, tidak hanya dilakukan oleh Anis dalam novelnya pada tokoh Alina Suhita, tetapi juga pada tokoh Rara Renggani. Dalam novel tersebut, tokoh Rara Rengganis diartikulasikan sebagai tokoh yang cerdas, mandiri, berani, kuat, berkepribadian mantap, dan mandiri, serta memiliki kecakapan. Pengidentifikasian tersebut dilakukan pengarang melalui pengonstruksian tokoh Rara Rengganis sebagai tokoh berjenis kelamin perempuan yang berwatak aktif dalam kehidupan sosial, dan pintar. Itu tampak pada kutipan dialog antara tokoh Mas Birru dengan Rara Rengganis berikut:

Kenapa gak drama tentang pendekar perempuan di Indonesia, Re? Atau wayang-wayang perempuan"

"Sebenarnya pengen banget. Waktunya belum ada. Jadi bertahap." Dia terkekeh. Lalu menjelaskan kalau dia tidak menangani langsung. Hanya bertanggung jawab membuatkan naskah saja. Dia sudah membentuk tim. Kebetulan saja dia punya sahabat kaya raya yang tinggal di Belanda dan menyukai seni. Sahabatnya ini mau mendanai pementasan anak-anak muda kreatif. Dia meyakinkan teman-temannya kalau ia akan tetap setia di dunia jurnalistik dan menjalani hobinya travelling dan sedikit sibuk di LSM. Drama-drama hanya kesibukan kecil.

"Berarti kapan-kapan bisa bikin film di pesantren ya, $R e ?^{\prime \prime}$

(Anis, 2019)

Kutipan narasi dan dialog di atas merupakan momen yang mengidentifikasi tokoh Rara Rengganis sebagai tokoh berjenis kelamin perempuan yang wataknya berantagonisme dengan stereotipe identitas perempuan muslim. Pengartikulasian kalimat "Dia meyakinkan teman-temannya kalau ia akan tetap setia di dunia jurnalistik dan menjalani hobinya travelling dan sedikit sibuk di LSM." oleh pengarang dikonstruksikan momen yang bermakna perempuan muslim sebagai sosok yang pintar, aktif, terbuka, dan berani, serta cakap dalam mengelola berbagai hal. Adapun pengonstruksian tokoh Rara Rengganis sebagai tokoh yang cerdas dan memiliki pengetahuan yang luas dilakukan oleh Anis melalui praktik pengartikulasian kalimat "Ia seperti Srikandi. Cantik, santun, berpengetahuan, dan dicintai Mas Birru." (Anis, 2019).

Dalam wacana pewayangan, Sri Kandi merupakan tokoh yang unik dan khas. Dalam wacana tersebut, Sri Kandi dipahami sebagai sosok perempuan titisan Dewi Amba. Sri Kandi adalah putri Raja Campala. Meskipun memiliki trah raja, Sri Kandi bukanlah pribadi yang sombong. Oleh karena itu, dalam wacana pemawayangan Sri Kandi dikenal sebagai tokoh yang sakti, berani, pintar, tetapi juga rendah hati (Ariani, 2016). Hal tersebut sebagaimana juga yang dinyatakan oleh Miranti dan Amzy. Menurut Miranti dan Amzy (2018) Sri Kandi merupakan tokoh dalam pewayangan yang memiliki karakter atau watak cerdas, pintar, dan berani. Hal tersebut tampak pada kutipan berikut:

Hal ini terbukti dari kepribadiannya yang 
rendah hati dan tidak merasa berkuasa padahal ia adalah anak seorang raja yang cukup ternama dikerajaannya itu. Srikandi tetap berusaha dengan kemampuannya sendiri. Ia tidak berpangku tangan atas apa yang sudah ia miliki, karna ia sadar semua itu hanya milik orang tuanya dan juga titipan. Oleh karena itu, Srikandi tetap rendah hati, tidak pernah puas diri dalam hal apa yang sudah ia miliki hanyalah titipan, ia akan terus mencari apa yang bermanfaat untuk dirinya (Miranti \& Amzy, 2018).

Karakter atau watak Sri Kandi merupakan antagonisme dari watak stereotipe perempuan yang ada di masyarakat. Pada masyarakat Indonesia, perempuan diidentifikasi sebagai mahluk yang bernegasi dengan laki-laki dalam tataran watak. Perempuan distereotipekan oleh masyarakat sebagai mahluk yang lemah, bodoh, penakut, tidak berkepribadian, tidak mandiri, dan tidak memiliki kecakapan apapun dalam kehidupan. Maka, antara watak Srikandi dan watak perempuan di masyarakat Indonesia terdapat antagonisme (Kartikawati, 2020).

Dalam Hati Suhita, pengartikulasian narasi Sri Kandi yang direlasikan dengan tokoh Rara Rengganis merupakan praktik pembangunan wacana identitas perempuan muslim yang berantagonisme dengan stereotipe perempuan yang terdapat di masyarakat. Adanya elemen Sri Kandi yang berelasi dengan elemen tokoh Rara Rengganis berdampak pada terkonstruksinya momen yang memaknai tokoh Rara Rengganis serupa dengan tokoh Sri Kandi dalam pewayangan. Oleh karena itu pada kalimat Ia seperti Srikandi. Cantik, santun, berpengetahuan, dan dicintai Mas Birru." terbangun makna wacana tentang perempuan muslim sebagai perempuan yang memiliki watak serupa Sri Kandi. Jadi, identitas perempuan muslim yang tidak serupa dengan apa yang dimiliki oleh Sri Kandi dalam tataran perwatakan diletakkan oleh Anis dalam medan kewacanaan.

Dalam Hati Suhita pemahaman mengenai perempuan sebagai liyan atau subjek subordinat dalam budaya patriarki seakan menemui gugatan. Melalui tokoh Alina Suhita dan Rara Rengganis, Khilma Anis seakan ingin mengartikulasikan sebuah diskursus kritis mengenai perempuan dalam budaya patriarki. Melalui aksi dan dialog kedua tokoh perempuan tersebut, Khilma Anis memberikan pemahaman dan gambaran kepada pembaca bahwa budaya patriarki adalah budaya yang tidak pantas untuk terus dirawat keberadaannya. Pemaknaan terhadap kedudukan perempuan dalam sistem budaya tersebut harus direvisi karena perempuan adalah mahluk hidup yang sama diciptakan Tuhan, oleh karena itu ia harus mendapatkan hak yang sama dengan laki-laki.

Dalam novel tersebut, diskriminasi terhadap perempuan dalam budaya patriarki ditampakkan pada peristiwa perkawinan paksa yang dialami oleh tokoh Alina Suhita. Praktik perjodohan atau perkawinan paksa merupakan tradisi yang berkembang di masyarakat Indonesia, khususnya Jawa. Di masyarakat Jawa yang cenderung bersifat konservatif dan ortodoks, seorang perempuan tidak memiliki hak untuk memilih jodohnya sendiri. Itu sebagaimana yang tampak pada kutipan berikut:

"Perjodohan itu tidak ada dalam kamus hidupku. Aku ini aktivis. Aku teriak setiap hari soal penindasan. Soal memperjuangkan hak asasi. Kawan-kawan menertawakanku karena aku tidak bisa memperjuangkan masa depanku sendiri. Semua kawanku kecewa dengan perjodohan ini" (Anis, 2019).

Di era yang semakin maju dan mengglobal ini, pernikahan yang berdasar pada sistem perjodohan paksa sudah dianggap tidak relevan. Hal tersebut disebabkan oleh ketidakrelevanan pemahaman perjodohan paksa dengan pengakuan atas hak-hak individu. Oleh karena itu, Khilma Anis, melalui Hati 
Suhita, seakan ingin mengartikulasikan gugatan kritis tentang praktik pernikahan paksa.

Sebagaimana yang telah disampaikan sebelumnya, pemaksaan terhadap hak hidup perempuan tidaklah tepat, karena perempuan, sebagai manusia, memiliki hak yang sama dengan laki-laki. Oleh karena itu, praktik diskrimanisi tersebut harus dihapuskan, atau setidaknya dikritisi keberadaannya. Perempuan bukanlah mahluk yang lemah, yang pantas diletakkan pada dataran periferal. Namun, upaya resistensi tersebut tidak bisa dilakukan tanpa adanya kepedulian perempuan itu sendiri terhadap hak-haknya. Mengenai pentingnya kepedulian perempuan untuk memperjuangkan hak-haknya juga tampak pada kutipan berikut (Anis, 2019):

Hari ini aku tahu, tidak sia-sia Mbah Kung menyematkan nama salah satu penguasa perempuan di kerajaan Majapahit dalam namaku, Suhita. Perang di hatiku sepanjang tujuh purnama ini begitu dahsyat. Kebekuan dan keangkuhan suamiku telah membuat hatiku tersungkur tak berdaya. Tapi aku tidak pernah menyerah. Aku melawannya dengan kelembutan, dengan ilmuku, sekaligus puja pintaku (Anis, 2019).

\section{Kesimpulan}

Berdasarkan analisis yang dilakukan dapat disimpulkan Hati Suhita adalah novel yang mengangkat wacana antagonisme atas stereotipe identitas perempuan muslim Indonesia. Dalam novel tersebut, momen-momen yang mengartikulasikan perempuan muslim Indonesia sebagai mahluk yang rendah hati, tabah, kuat, cerdas, dan berani diinklusikan ke dalam wacana. Adapun momenmomen yang dibangun dari relasi elemen-elemen yang mengidentifikasi perempuan sebagai mahluk yang lemah, bodoh, tidak berpendirian, dan tidak mandiri dieksklusi, ditempatkan dalam medan kewacanaan. Hal tersebut berdampak pada terkonstruksinya wacana identitas perempuan muslim sebagai wacana yang merepresentasikan identitas perempuan muslim sebagai mahluk yang cerdas, tabah, berani, mandiri, cakap dan berkepribadian kuat.

\section{Daftar Pustaka}

Fabriar, S. R. (2013). Potret Perempuan Dalam Film Perempuan Berkalung Sorban. Sawwa: Jurnal Studi Gender, 9(1), 27-44.

Anis, K. (2019). Hati Suhita. Yogyakarta: Telaga Aksara.

Ariani, I. (2016). Feminisme dalam Pergelaran Wayang Kulit Purwa Tokoh Dewi shinta, Dewi Kunti, Dewi Srikandi. Jurnal Filsafat, 26(2). https://doi.org/10.22146/jf.12786

Denzin, N. K., \& Lincoln, Y. S. (2009). Handbook of Qualitative Research. . Yogyakarta: Pustaka Pelajar.

(Terjemahan; D. Dariyatno, B. S. Fata, A. Abi, \& J. Rinaldi, eds.). Yogyakarta: Pustaka Pelajar.

El-Saadawi, N. (2011). Perempuan dalam Budaya Patriarkhi (Terjemahan; Z. Zulhilmiyasri, ed.).

Yogyakarta: Pustaka Pelajar.

Fabriar, S. R. (2013). Potret Perempuan dalam Film Perempuan Berkalung Sorban. SAWWA, 9(1).

Hanani, T. (2021). Kuasa semu laki-laki dalam Pengakuan Pariyem, Malam Terakhir, dan Baju: kajian bandingan berparas feminisme. SULUK: Jurnal Bahasa, Sastra, Dan Budaya, 3(1). https://doi. org/10.15642/suluk.2021.3.1.85-98 
Haryanti, N. D., \& Fakhriyah, F. N. (2020). Pesantren, Perempuan, dan Subaltern dalam Perempuan Berkalung Sorban dan Hati Suhita. SULUK: Jurnal Bahasa, Sastra, Dan Budaya, 2(2), 140-149. https://doi.org/10.15642/suluk.2020.2.2.140-149

Jorgensen, M. W., \& Phillips, L. J. (2007). Analisis Wacana: Teori dan Metode (I. Suyitno, L. Suyitno, \& S. Suwarna, eds.). Yogyakarta: Pustaka Pelajar.

Kartikawati, D. (2020). Stereotype Perempuan di Media Film: Obyek, Citra dan Komoditi. Syntax Literate; Jurnal Ilmiah Indonesia, 5(3). https://doi.org/10.36418/syntax-literate.v5i3.975 Laclau, E., \& Mouffe, C. (2008). Hegemoni dan Strategi Sosialis: Postmarxisme dan Gerakan Sosial Baru (Terjemahan; E. P. Darmawan, ed.). Yogyakarta: Resist Book.

Miranti, D., \& Amzy, N. (2018). Analisis Karakter Tokoh Wayang Srikandi dalam Lakon Perang Bahratayuda sebagai Pembelajaran Karakter untuk Remaja. Visual Heritage: Jurnal Kreasi Seni Dan Budaya, 1(01). https://doi.org/10.30998/vh.v1i01.8 